\title{
The Effect of Social Media on Employees' Job Performance: The mediating Role of Organizational Structure
}

\author{
Ali Sukru Cetinkaya \\ Selcuk University \\ Muhammad Rashid \\ Selcuk University
}

Social media is creating a drastic change at workplaces, and organizations are increasingly interested in adaption of it for their business processes. The aim of social media usage at workplace may differ but ultimate objective is to build social networks and sharing. This empirical research examined the effect of use of social media on employees' job performance and the mediating effect of an organizational structure. Survey data gathered from 205 valid responses and analyzed by structural equation modeling technique. Results revealed that "use of social media" is positively correlated with "employees' job performance", while organizational structure has positive mediating effect.

\section{INTRODUCTION}

Social media is a platform through which people connect or collaborate with one another inside and outside the organizations (Daowd, 2016, p. 33). Social media not only provides a complete knowledge management but also provides very simple and flexible tools to the management (Cao \& Ali, 2018, p. 70). Currently, the available social media applications (e.g. Facebook, twitter and LinkedIn) are playing an important role in human interaction within organizations. Employees use online applications at workplace because these applications brings efficiency in operations.

Social media has become an important need for organizational design in this competitive environment (Kane, 2017a). Organizations may face opportunities, threats, weaknesses and strengths owing to use of social media (Kane, 2017a; Tajudeen, Jaafar, \& Ainin, 2018). For instance, social media provides opportunity in terms of uploaded information may be beneficial for the organization. On the other hand, it may become a threat, competitors may use shared information. Similarly, social media can be weakness for the organizations when it negatively affects its productivity. Social media may become the strength for the organization when it is used to develop a relationship and used to build the capacity of the employees. Even though social media plays an important role on an employees' job performance, minor importance was given to the use of social media at workplace.

Social media usage at the workplace increases the capacity of the employees (Fusi \& Feeney, 2016). Since employees use social media for their personal and official activities at workplace; they get more knowledge and increase their ability related to their work by using social media. Furthermore, integrated 
social media at workplace reduces the workload and increases the usefulness of social media (Fusi \& Feeney, 2016, p. 6). This advantage drives the organizations to develop a deeper understanding of social media platforms and use it effectively (Betsy A. Pudliner, Eric T. Brey, \& Hyeong-Gyu Choi, 2015, p. 406).

The effects of organizational structure on organizational effectiveness are the degree to which an organization achieves its objectives (Tran \& Tian, 2013). Literature concludes that a formal structure is shaped in a dynamic environment which negatively affects organizational effectiveness (ibid). Companies that do not have the resources to invest in a large-scale for technology infrastructure, now have the opportunity to leverage multiple social media applications to participate in community building activities (Young, 2017, p. 45).

Although the concepts of social media, job performance and organizational structure have wider implications within the organizations, there is no conclusive evidence from previous research identifying the relationship among these variables. Therefore, this research aimed to fulfil the identified gap and provides practical implications to the practitioners.

\section{SOCIAL MEDIA}

Social media is a group of Internet-based applications that built on the ideological and technological foundations of Web 2.0 (Tajvidi \& Karami, 2017, p. 2). Social media provides social network identity to its users to establish profiles for social activities and also allows to its users to create and exchange usergenerated content without any time and space constraints (Carr \& Hayes, 2015; Kaplan \& Haenlein, 2012, p. 101; Özdemir \& Erdem, 2016). Therefore, social media introduced a new communication paradigm for organizations by providing two-way communication channels unlike traditional media.

Social media is a systemized network consisting three parts: devices that produce information, devices that fetch information and people that use information for their official and personal purpose (Carr \& Hayes, 2015, p. 40). These social networks provide searching and privacy features to their users. In addition, users can also articulate a list of other users with whom they share and interact (Gerald C. Kane \& Maryam Alavi, 2012, p. 11).

Social media is a platform where organizations interact with their stakeholders. Therefore, organizations are increasingly interested in the use of social media to build relationships with employees and other stakeholders (Macnamara \& Zerfass, 2012, p. 288; Nga Ling Chan \& Guillet, 2011, p. 355). Social media applications like Facebook, social networking sites and LinkedIn enable organizations to engage their customers in an ongoing dialogue (Goldkind, 2015, p. 380). Furthermore, organizations use social media to promote their products and services to increase their customer's strength (Aichner \& Jacob, 2014, p. 259).

There are many social network applications available that organizations use for their official purposes such as Facebook, WhatsApp, YouTube, Twitter, Blogs, Skype and Photo-sharing sites. In addition, some special and private social networks are also used for communication in the organizations such as "Yammer", whereas small number of organizations use podcast, second life and Pinterest (Macnamara \& Zerfass, 2012, p. 296).

Facebook is one of the largest social global networks that has come the forefront among social networking sites. Facebook constantly improving and renewing its features to meet the demands of their users. It basically facilitates its users to create their profiles, social pages, groups. In addition, Facebook provides the facilities of messages, notifications of events, games, and calls. (Islek, 2012, p. 57). Twitter lies in the micro blogging category of the social network wherein users can exchange messages using smart devices. It is only a text based application, users can only write up to a maximum length of 140 characters This limitation changed to 280 characters after 7 November 2017 (Usher, 2011, p. 326). Skype is also an internet-based application for communication. Skype not only allows its user in voice communication but also provides the facility of video calls through internet. Calls from skype to skype are free except when making calls skype to landline or mobile (Usher, 2011, p. 326). YouTube is largest site for video sharing (Madsen \& Slatten, 2015, p. 6). YouTube has made it possible for everyone to 
watch, share, and download videos across the world (Usher, 2011, p. 327). Blogs maintained by its users in form of websites. Users update it by commenting, videos sharing and writing the descriptions of any event. Blogs are used by individuals and companies to post news and other informative materials (Aichner \& Jacob, 2014, p. 259; Usher, 2011, p. 326).

Switching to mobile devices has been an important development of social media in recent year (Perrin, 2015, p. 3). Interactions on social networks are now possible through mobile devices. In developing countries phones are the primary source of accessing the internet. Having access to social media platform mobile oriented applications enable the people to share knowledge from everywhere and anytime (Kane, 2017b, p. 41).

Use of social media has been classified in three ways. First, social media is used by people for socializing and strengthening relationships among friends, relatives and colleagues. Second one is hedonic use where people use social media for the affective need of pleasure and emotional experiences. Third is cognitive use, in this way one uses social media to fulfil his needs by freely searching for information and knowledge (Ali-Hassan, Nevo, \& Wade, 2015a, p. 67).

Social media provides a better platform of understanding how people develop networks and share information with each other. For instance, social exchange theory explains that individuals engage with each other on the base of cost-benefit framework. Concisely, individuals bound in communication with each other to gain reward. Similarly, social penetration theory states how individuals develop relations through self-disclosure (Pan, 2012, p. 9).

\section{EMPLOYEES' JOB PERFORMANCE}

Job performance refers to the quality of work of an employee (Caillier, 2010, p. 140). Job performance is associated with the ability of the employees being aware of assigned targets, fulfilling expectations and achieving targets or accomplishing a standard set of tasks for the organization (Sethela June \& Mahmood, 2011, p. 96). Job performance is directly related to the efficiency of the employee because employees' performance tends to increase due to a system of stress reduction in the workplace (Kumasey et al., 2014; Haque, Aston \& Kozlovski, 2018). The organizations which are well aware of this fact have fully concentrated on the factors that affect the employees' job performance (Dinc, 2017, p. 774).

There are number of factors (internal and external) that affect job performance or the success of an employee in an organization. Individual ability, knowledge and skill can be examples of internal factors while the working environment, characteristics of assigned tasks, incentive, organizational structure and Human Resource Management practices are examples of external factors (Lu, Guo, Luo, \& Chen, 2015, p. 287; Meriçöz, 2015, p. 44; Sani \& Maharani, 2015, p. 186).

Several studies have examined the dimensions of employees' job performance as task performance, contextual performance, adaptive performance, creative performance, agility performance and effectiveness (Catalsakal, 2016, p. 17). Task performance is directly related to the technical aspects of the organization and it supports the core of any organization either by executing its processes or maintaining its required services (Harari, Reaves, \& Viswesvaran, 2015, p. 498; Uryan, 2015, p. 3). Borman and Motowidlo (1997) defined task performance as "the effectiveness with which job incumbents perform activities that contribute to the organization's technical core" (Cited in Liua, Jiangb, \& Chen, 2016, p. 4). Task performance support the core of any organization either by executing its processes or by maintaining its required services (Harari et al., 2015, p. 498).

Contextual performance is the behavioral patterns that support the psychological and social context in which task activities are performed (Stone-Romero, Alvarez, \& Thompson, 2009, p. 104). Contextual performance includes the behaviors of employees for activities other than core job, such as helping, supporting the colleagues at workplace, showing learning attitude, sharing information and doing work for others which are not one's responsibility (Tufail, Mahesar, \& Pathan, 2017, p. 272). Contextual performance contributes to help, cooperate and suggest the methods to improve the organizational 
processes. In other words, contextual performance is a behavior that contributes to the organization by coordinating with colleagues, following rules, and putting extra efforts (LI \& Lu, 2009, p. 3).

Adaptive performance is how versatile employees are in understanding and adopting to changes taking place in the organization. The organizational support at workplace increases organizational commitment, which tends to increase the individual and collective performance of employees (Haque \& Yamoah, 2014; Haque \& Aston, 2016). Researchers classified adaptive performance as a new way of task learning, handling stress at working, adaptability of new technologies and procedure, problem solving and interpersonal adaptability (Uryan, 2015, p. 4).

Creative performance is the ability to generate products, procedures or ideas that are viewed as original and potentially useful. Manager generally assess an employee's contribution on creative performance. Practically, creativity of employee contributes to the output of the organization. Thus, employees individually crop new ideas related to different work description and procedures (Uryan, 2015, p. 4). Indeed, employees having strong social interaction throughout the workday, are generally more positive, productive and they show their creative attitude at workplace (Hernandez, Stanley, \& Miller, 2014, p. 342).

Agility performance is the ability of an employee to adapt changes for personal and organizational benefits. Employee feels comfortable with changes, new idea and technology via commitment to continuous learning. Dimensions of agility performance are proactivity, resilience and adaptability. These dimensions require employees to challenge themselves by expanding their skills through continuous learning and exploring (Cai, Huang, \& Liu, 2018, p. 54).

Use of social media at workplace may negatively affect the job performance (Jana Kühnel, Tim Vahle-Hinzc, \& Bloom, 2017). For example, social media usage at workplace lead the employee to misuse of organizational resources, official time, and has often been perceived as an employee deviate from the work place, violating the standard operation procedures of the organization. Consequently, social media weakens the employee job performance (ibid). However, researchers believe that practitioners can increase the efficiency and productivity of the employees by adopting social media in business processes (Levy, 2013, p. 742).

\section{ORGANIZATIONAL STRUCTURE}

Organizational structure is the formal allocation of work roles, administrative mechanism, integrate activities, and setting up of communication channels, authorities, responsibilities and accountabilities at different levels within the organization (Ajagbe, Cho, \& Udo, 2016, p. 65; Wahba, 2015, p. 279). In short, it is about how organizational activities are assigned and monitored to achieve organizational objectives. Factors that influence organization's structure are grouped into two categories: internal and external factors (Tran \& Tian, 2013, p. 229). External factors affect structure however, these factors are not in the direct control of the organization whereas the internal factors are measurable, comparable, and directly controlled by the organization (ibid).

Various types of organizational structures identified according to organizational operational functionality (Janićijević, 2017, p. 72). A functional organizational structure is formed according to the characteristics like work, product, geography and project of the organization (ibid).

Since organizational features do not focus on single feature thus, many researchers have explained organizational structure in different dimensions. It has distinctive dimensions such as flatness, centralization, decentralization, formalization, complexity (hierarchy), integration and specialization (Hao, Kasper, \& Muehlbacher, 2012, p. 36; Özlem Çetinkaya Bozkurta, Adnan Kalkanb, \& Armanc, 2014, p. 223; Wahba, 2015, p. 279).

Centralization, decentralization and formalization are the most important components of organizational structure (Shaar \& Khattab, 2015, p. 501). Centralization in organizational structure refers to the "decision making authority". In a centralized structure, decisions are made at the top level in the organization. It creates a non-participatory environment and affects the commitment, communication and involvement of tasks among individuals. A highly centralized structure in the organization reduces the 
opportunity and growth of individuals and affects creative problem solving (Wahba, 2015, p. 279). Centralization may cause an interruption of communication and the frequent sharing of new ideas because it consumes time following formal communication channels (Özlem Çetinkaya Bozkurta et al., 2014, p. 224).

Authority of decisions making in a decentralized structure refers to the lower level. There is a trend of having decentralized structure in organizations with self-managed groups. These groups are smaller, more technological and increased the use of open communication. The biggest step is to reduce the boundaries between the functions and operation, and emphasis that all departments should work for the common goals of the organization (Sujarwoto, 2017, p. 2)..

Formalization in organization structure is the degree to which the organization follows the predefined rules and procedures. High degree of formalization in an organization can be measured by how much the organization is concerned in imposing strict standardized written documents, work process and defined rules and procedures (Delic \& Ahmetovic, 2013, p. 36; Tran \& Tian, 2013, p. 229).

Unlike other structures, matrix organizational structure shares the power along and among two or more dimensions (dual supervisor to report). In matrix structure, individuals work under vertical and horizontal chain of commands. The main advantage of a matrix organization is that the employee is accountable to the immediate supervisor and project manager. Matrix organizational structure provides a platform to the matrix manager to control individual's expertise without being concerned about divisions in the workplace (McPhail, 2016, p. 58). Similarly, team structure is suitable to perform interdependent tasks. This type of structure helps to develop common skills, increase the pace of professional decision making and provides a platform for learning and knowledge sharing in the organization (Acharya \& Mishra, 2017, p. 967).

Flatness refers to organizational structure in which small number of hierarchy level and small number of chain of command exist (Huang, Kristal, \& Schroeder, 2010b, p. 517). Few numbers of level increases flexibility, reduces expense and hierarchical load in the organization. Participants can share information and interact with each other easily without a long approval process, ultimately, improves employee's job performance (M. Zhang, Zhao, \& Qi, 2014, p. 146).

Complexity (and hierarchy) in organizational structure refers to the degree of differentiation within the organization (Delic \& Ahmetovic, 2013, p. 37). Hierarchy reflects how many employees can be effectively manage by one manager. It also shows a relationship between the immediate supervisors and subordinates (ibid). The hierarchy of an organization can be measured by horizontal, vertical and spatial differentiation (Delic \& Ahmetovic, 2013, p. 37). Horizontal differentiation distinguishes in respect with task undertaken and occupational members of the organization. Vertical differentiation refers the degree of span control or level in the hierarchical level. Spatial differentiation refers the geographically division level within the organization (Özlem Çetinkaya Bozkurta et al., 2014, p. 224).

Specialization refers to the degree in which works are divided into small and specified tasks. High degree of division of work means narrow and low division of work, which reflects a broad specialization. Vertical specialization of the higher level can create monotony and alienation at the workplace (Delic \& Ahmetovic, 2013, p. 36). Whereas, integration in organizational structure refers to the degree where organizational activities are coordinated by adopting formal mechanisms of coordination (ibid).

\section{RESEARCH HYPOTHESES}

Social media, job performance and organizational structure serve as the conceptual and theoretical foundation for this research. Social media technologies have changed the ways of interaction and information sharing on the web. Moreover, Web 2.0 technology enables the organizations and customers interaction and sharing information through blogs, wikis, podcasts, Facebook and WhatsApp (Usher, 2011). As social media technologies are based on mutual communication between two or more parties, so it is very important to explore interaction between both sides within organization (Reitz, 2012, p. 48).

The relationship between job performance and organizational structure is unexpectedly dissymmetrical where organizational structure has great impact on job Performance (Nisar, Rodríguez- 
Monroy, Ruiz, \& Yuxi, 2012, p. 176). Since the organizational structure has a close relationship with the employees' job performance, so different organizational structures lead organizations to different work efficiency methods and performance (Kane, 2015; Kjaerulff, 2015).

In different organizational structures social media is used in different ways. In other words, it has its benefits and limitations. Therefore, employees perceive and interpret the influence of organizational structure differently (Scott \& Davis, 2014). In addition, social media allows customers to exchange information with one another. This peer to peer interaction advocates in favor of the organization and influences behavior of customers (Sashi, 2012, p. 255).

Literature points out that social media applications have impact on job performance. Social media applications contribute to make the communication process more efficient and ultimately increases employee job performance (Louie H. M. Wong, Carol X. J. Ou, Davison, Hui Zhu, \& Zhang, 2016, p. 240). For instance, in organizations workers use social media for official and personal use. Relatively official purpose it facilitates the employee when problem arise offline (Dunne, Lawlor, \& Rowley, 2010, p. 53). However, organizations have different point of views about the use of social media (White, 2014). Some are positive and other are very concerned about the use of social media at work as accusing it decreasing employee job performance (Sykes, Venkatesh, \& Johnson, 2014, p. 51).

Employees who use social media at workplace not only seek and share information, but also consider it as a platform for meeting friends, gaining a sense of belonging and build relationships (Atsan \& Çetinkaya, 2015). Especially when employees work at different locations they connect each other through social media for common interests. In short, use of social media at the workplace is useful for developing professional networks and strengthening links with workmates (Cao, Guo, Vogel, \& Zhang, 2016, p. 532).

Research conducted by Zhang \& Venkatesh (2013) on implication of social media on job performance concluded that social media has positive effect on employee' job performance. Furthermore, it is identified from the literature that the use of social media saves time and cost, and ultimately increases the profit of organizations (Harandi \& Abdolvand, 2018, p. 29). Social media also has impacts on innovation, advertising, and customer relations in organizations (Tajudeen et al., 2018, p. 310). In the line of previous research, this article proposes following hypothesis:

$\mathrm{H}_{1}$ : Social media has a positive effect on employee' job performance.

Organizational structure plays a vital role in achieving organization goals. An organization's intention is to increase its performance by adopting efficient structures. A flexible organizational structure allows workers to work freely and perform according to their customer needs. Such types of structures give way for a pro-active role and increases the employee job performance (Shafiee, Razminia, \& Zeymaran, 2016, p. 161).

Social media creates a direct and prompts relationship between the organization and its audience. By using social media, employees are maintaining their relationships for quick and efficient problem solving. However, few organizations succeed in such kind of relationships. Because there are many structural design elements that restrict employees (Kjaerulff, 2015, p. 4). Emergence of new trends on social media push organizations to become more involved and makes them adopt to new social media applications so as to keep their organization structure up to date. Organizations are keen and interested in its appropriate use hence understanding its effectiveness. In fact, social media has become a necessity at the workplace (Langer, 2014, p. 4). Based on the literature, following hypothesis was proposed:

$\mathrm{H}_{2}$ : Organizational structure has a positive mediating effect on the relationship between use of social media and employee' job performance. 


\section{RESEARCH METHOD}

The research examines the mediating effect of organizational structure in the relationship between the use of social media and job performance in the service sectors. A 5-points Likert scale ranging from "1. Strongly disagree" to " 5 . Strongly agree" survey questionnaire was circulated for data collection. The questionnaire consisted of four parts: the first part was the measure of use of social media, second part was the measure of employee job performance, third part was the measure of effects of organizational structure and the fourth part was about the participant's demographic information.

The scale of the organizational structure adopted from the research of (Huang, Kristal, \& Schroeder, 2010a), (Liao, Chuang, \& To, 2011), (Akkoc \& Erdogan, 2011), (Delic \& Ahmetovic, 2013), and (haman, 2016)The measure consisted of 29 items with six dimensions. Internal consistency level (Cronbach's Alpha) of this scale was calculated as $\alpha=0.868$, which is at a high level. The 0.7 is a threshold value and above this is widely accepted in social sciences (Faizan \& Zehra, 2016).

The measure of employees' job performance adopted from, (Koopmans \& Bernaards, 2014) and (Coole, 2003) consisted of 20 items with two dimensions. Item 7 of the measure was a reverse coded item. Reliability analysis of this scale was calculated as $\alpha=0.871$. High alpha $(\alpha)$ value show the high internal consistency of the scale.

The scale used to measure the use of social media was adopted from, (Wang, Yang, \& Chen, 2016). It measured 10 items with two dimensions. Reliability analysis (Cronbach's Alpha) of the scale was calculated as $\alpha=0.941$, which showed that internal consistency is at high level in this scale.

The target audience of this survey was employees working in the service sector of Konya. The segment was unidentified. A simple random sampling technique was used to determine the sample. Formal permission was granted by concern authorities for data collection and participants voluntarily participated in this research. Participants filled questionnaires willingly and the aim was to contribute to the informed consent. A total of 300 questionnaires were distributed among different organizations. However, 236 questionnaires were received (68\% return rate). The detailed analysis revealed that 205 out of 236 returned questionnaire were completed and therefore, used for the purpose of analysis. For the validation of the sample size, Exploratory Factor Analysis, Confirmatory Factor Analysis, and Structural Equation Modelling was carried out and it estimated that the sample size was adequate (Hox \& Bechger, 2006).

\section{Demographics}

According to the demographic data of the participants (Table 1) shows majority of the respondents were married males having bachelor's degree and in the age group 25-34 years. Majority of the participants were working in existing organizations for the period of 4-6 years. Most of the participants had work experience of 10-15 years. When participants were categorized according to their departments, it was found that majority of participants belonged to structure control department.

Majority of the companies have been operating for more than 20 years. More than half of the companies surveyed had more than 500 employees. The legal status of the companies surveyed were mostly cooperate, public and limited companies. Banking, energy, water and sewage were mostly surveyed as the service providing sectors in this research. 


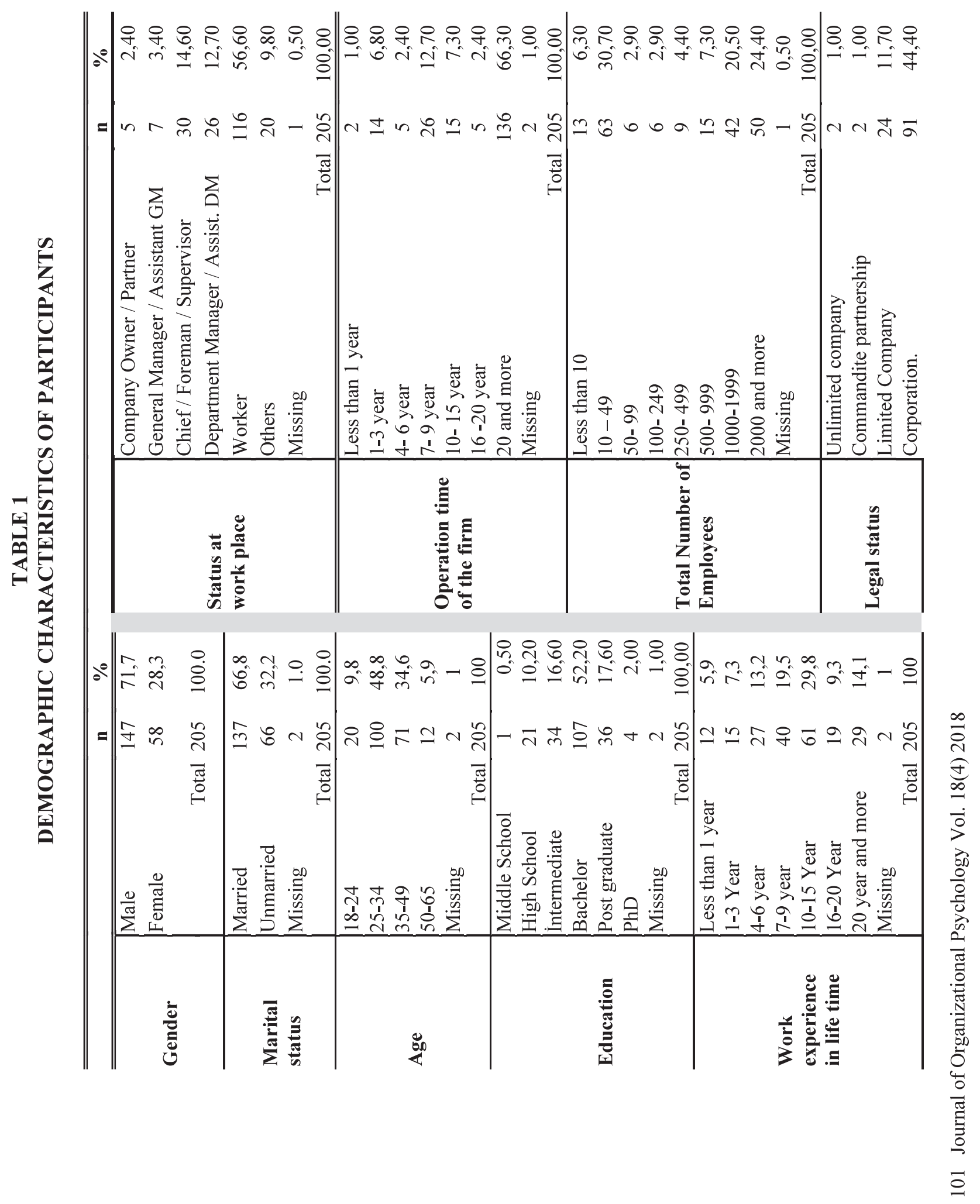




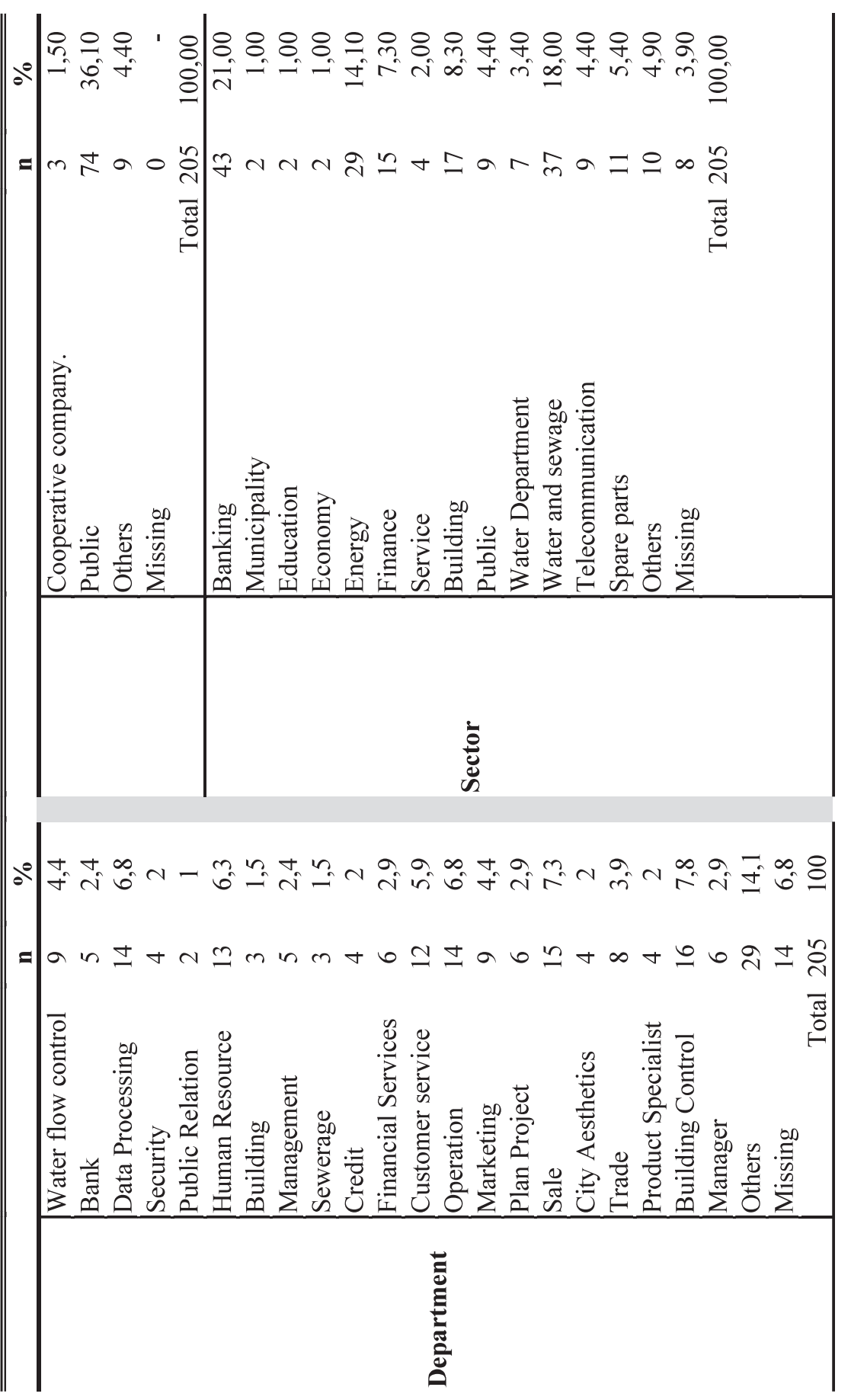




\section{Explanatory Factor Analysis for the Measure of Use of Social Media}

Exploratory Factor Analysis (EFA) operates on the notion that measurable and observable variables can be decreased to fewer latent variables that have a common variance and are unobservable. It is also known as reducing dimensionality (Bartholomew, Knott, \& Moustaki, 2011). In order to perform a factor analysis, a univariate and multivariate normality must be present in the data and the determining factor will be based on the assumption that correlations have a linear relationship between factors and variables (Yong \& Pearce, 2013, p. 67).

TABLE 2

\section{USE OF SOCIAL MEDIA EXPLANATORY FACTOR ANALYSIS (N= 205)}

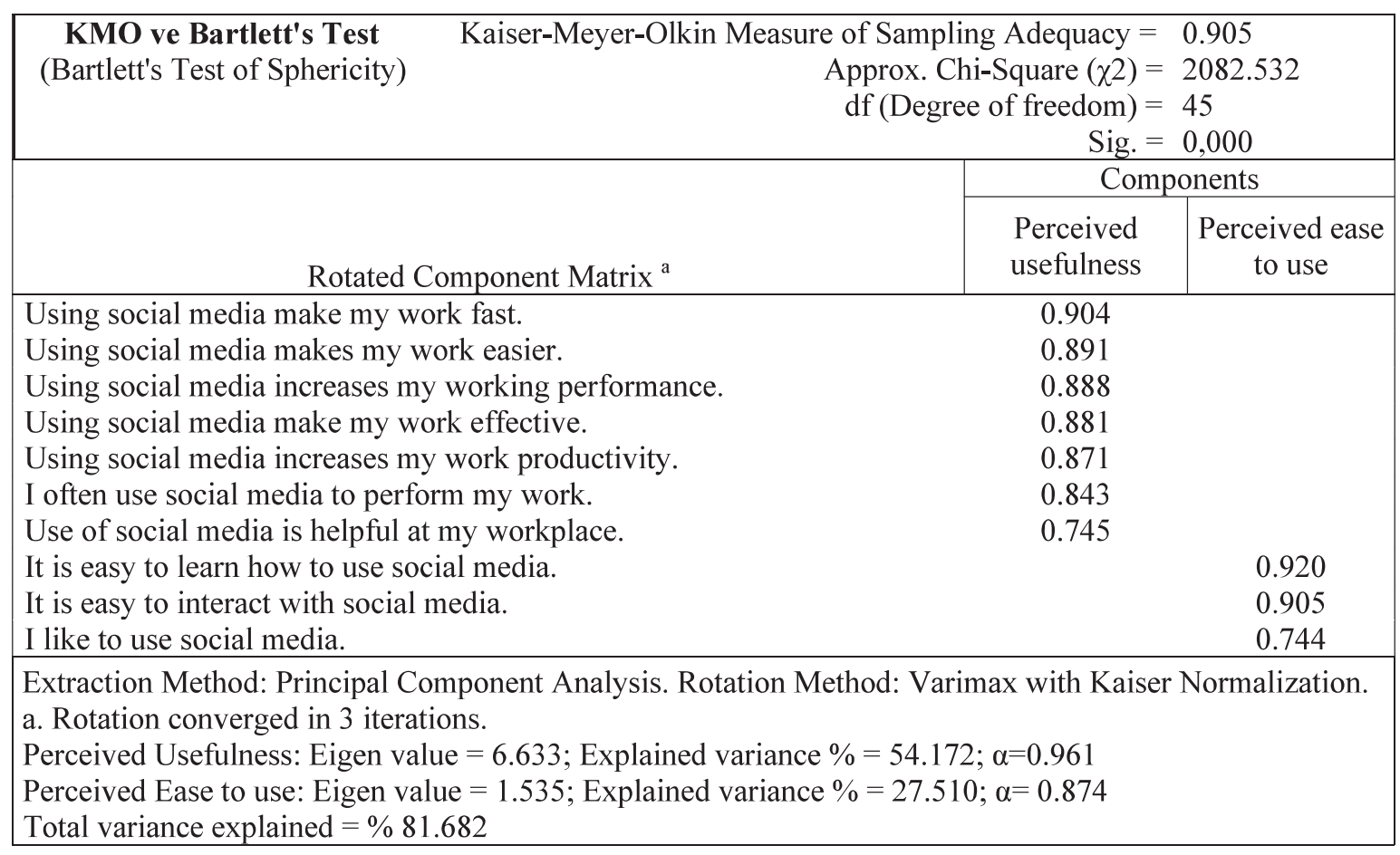

Table 2 reveals the results of EFA of the measure "use of social media". The sample adequacy test (KMO) value was 0.905 . The fact that the KMO value is higher than 0.80 indicates that the variables are related to each other, share common factor and were patterned relationships between items. The Bartlett's Test of Sphericity test, tests the hypothesis that the correlation matrix is equal to the unit matrices and had a statistically significant result of $(\chi 2=2082.532, \mathrm{df}=45, \mathrm{p}<000)$.

EFA brought out two dimensions of the measure use of social media: perceived usefulness and perceived ease to use. The perceived usefulness of social media eigenvalue was 6.633 with a variance explained as $54.172 \%$. The perceived ease to use component eigenvalue was 1.535 with a variance explained as $27.510 \%$, both components represented a total of $81.682 \%$ of the total explained variance. The reliability $(\alpha)$ coefficients of the components were higher than 0.80 . Compound variables were generated as suggested by the EFA and further data analysis conducted with these variables.

\section{Explanatory Factor Analysis for the Measure of Organizational Structure}

Table 3 reveals results of the EFA on the measure of organizational structure. The sample adequacy test (KMO) value was 0.802 . This value indicated variables associated with each other and that share a common factor. The Bartlett's Test of Sphericity test, showed that a variable organizational structure was statistically significant $(\chi 2=1880.435, \mathrm{df}=276, \mathrm{p}<000)$. 


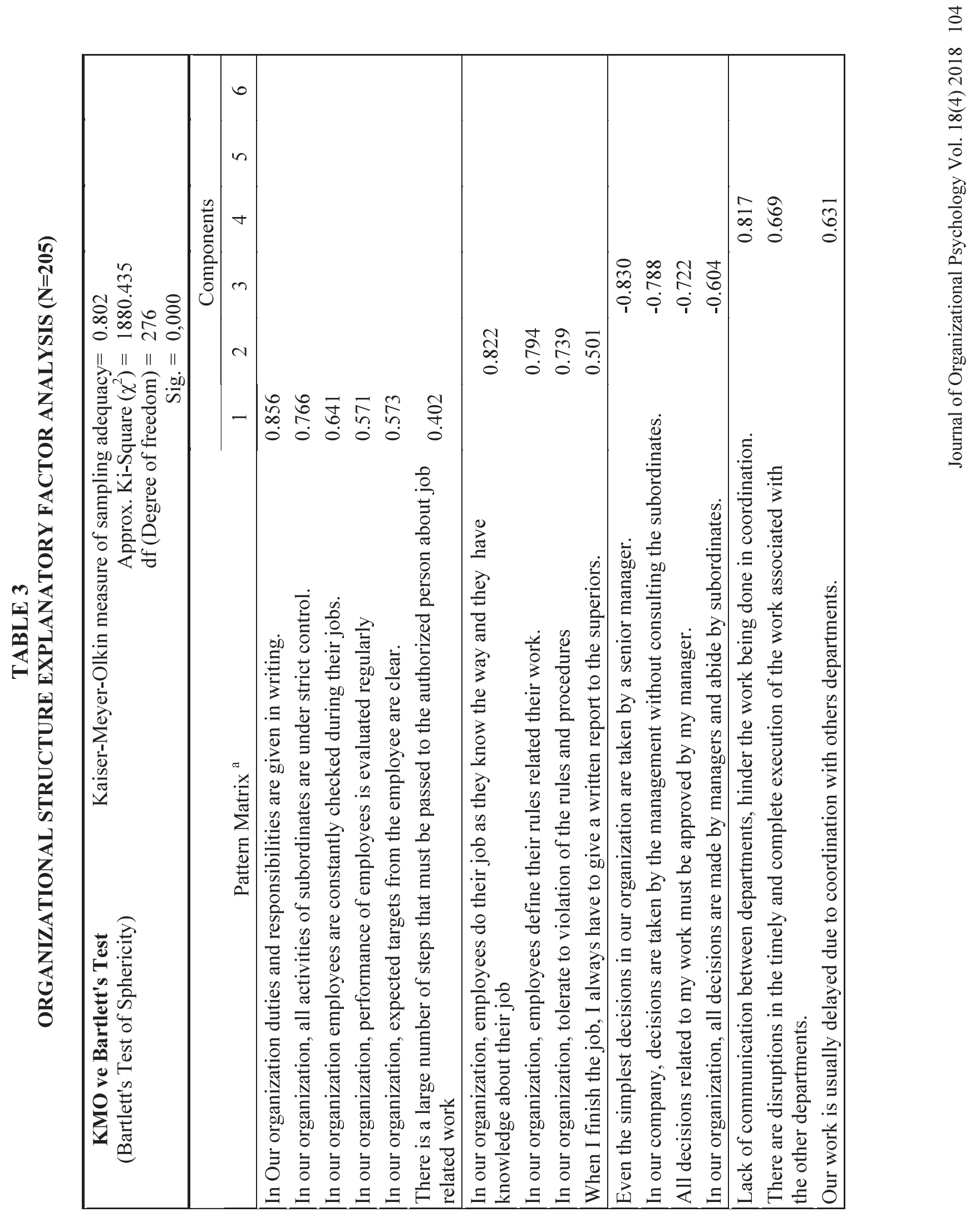




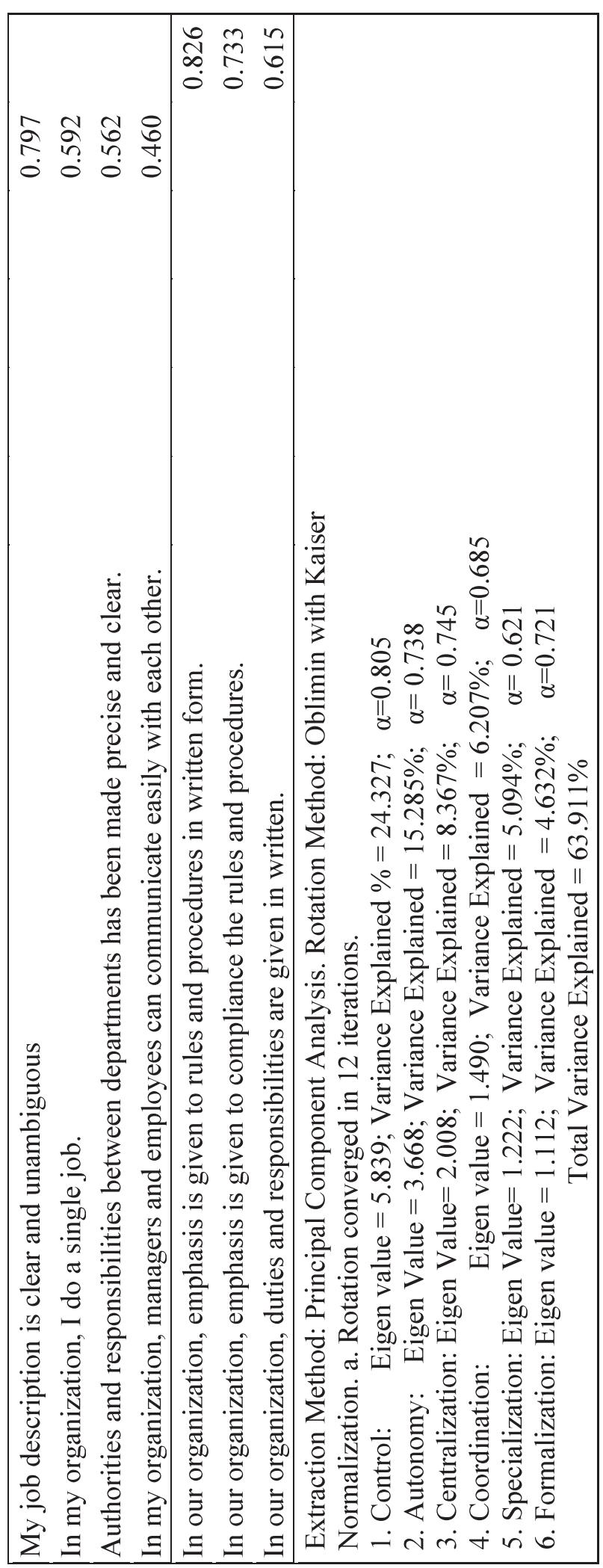

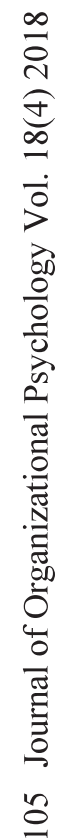


The EFA generated six dimensions of the measure on organizational structure: control, autonomy, centralization, coordination, specialization and formalization. In the course of factor analyzing five items were removed because they were loaded with more than one component simultaneously. The eigenvalues, variances explained and the reliability $(\alpha)$ coefficients of the components were presented in Table 3 . The components have an eigenvalue of above 1 explained as $63.11 \%$ of the total variance.

\section{Explanatory Factor Analysis for the Measure of Analyzing Employee Job Performance}

Table 4 shows the results of EFA on the measure of job performance. The sample adequacy test (KMO) value was 0.874 . This value indicates that the variables were associated with each other and shared a common factor. The Bartlett's Test of Sphericity test, showed that variable use of job performance was statistically significant $(\chi 2=1383.586, \mathrm{df}=153, \mathrm{p}<000)$.

Depicted in table 4 explanatory factor analysis generated three dimensions for the scale use of employee job performance: time management, task performance and contextual performance. The eigenvalues, variances explained and the reliability $(\alpha)$ coefficients of the components were presented in Table 4. In the course of factor analysing, five items were removed because they were loaded with more than one component simultaneously. The components have an eigenvalue above 1 explained as $64.021 \%$ total variance. 
TABLE 4

EMPLOYEE JOB PERFORMANCE EXPLANATORY FACTOR ANALYSIS (N=205)

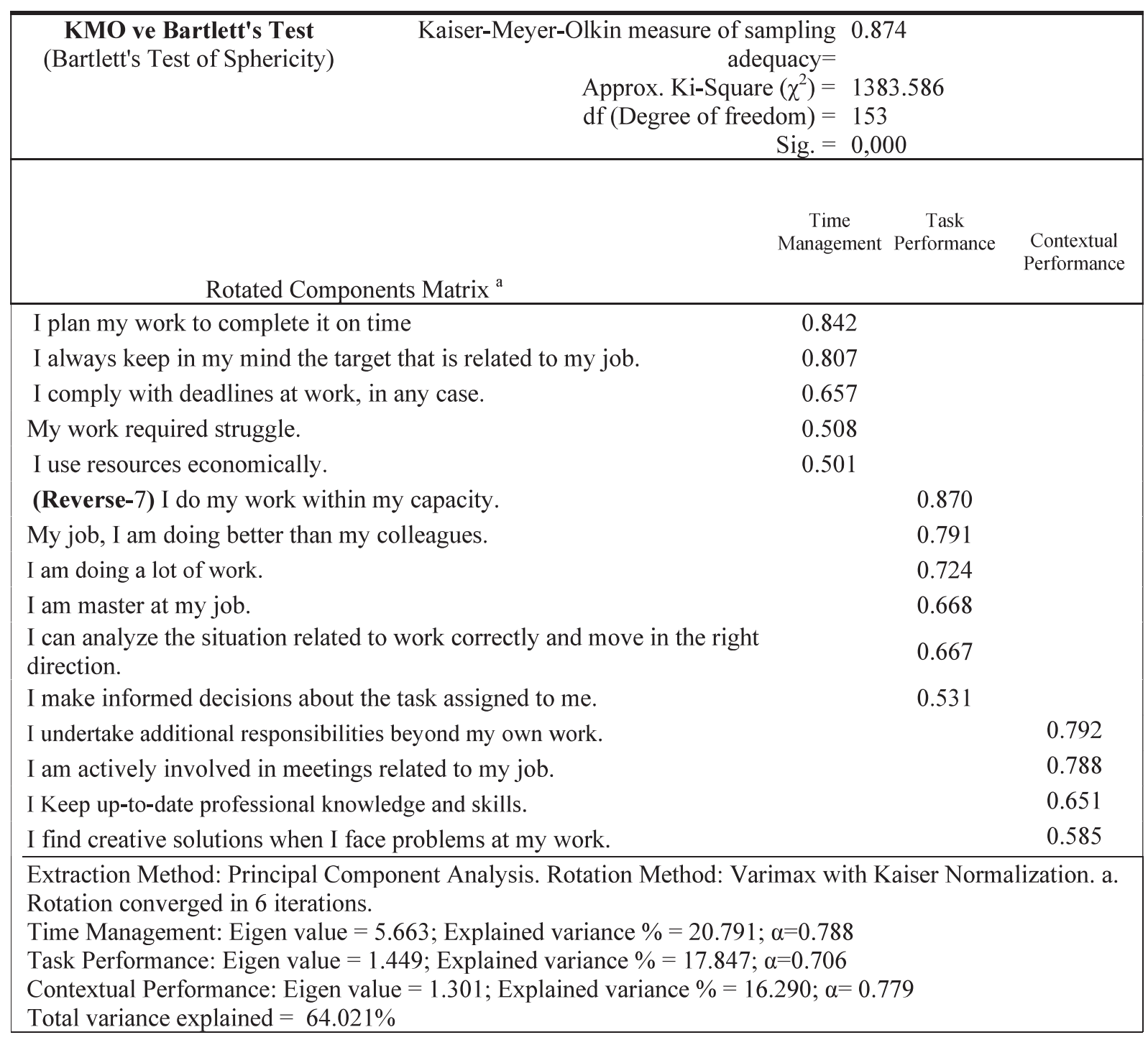

\section{Confirmatory Factor Analysis}

Confirmatory Factor Analysis (CFA) is a most commonly used multivariate technique for evaluating the validity of a measure. It allows the researcher to set a model on data and test how well the model is "fit". Statistical applications provide many "goodness-of-fit" statistics, which determined how well the implied variance-covariance matrix of the proposed model corresponds to the observed variancecovariance matrix. (i.e. how items of the instrument actually correlate (Veale, 2014, p. 165). CFA allows modelling of error variance, and testing for acceptable fit of the factor structure (Marsh, Morin, Parker, \& Kaur, 2014, p. 86).

In order to determine, whether the constructs of social media, organizational structure, and job performance are significantly fit, confirmatory factor analyses were applied by using IBM SPSS Amos software. The criteria used to assess the fitness of these models were chi-square significance, chi-square to degree of freedom ratio, RMSEA (root mean square error of approximation, AGFI (adjusted goodness of fit index) and GFI (goodness of fit index) (Catalsakal, 2016, p. 49). 
The model tested two components of the measure use of social media, consistent with the results of the EFA conducted using principal component analysis 7 items were loaded onto the first factor named usefulness; 3 items loaded on the second factor; named ease to use. The CFA for the scale social media was concluded as a fit model $(\chi 2=94.416 ; \mathrm{df}=32 ; \mathrm{P}=0.00, \chi 2 / \mathrm{df}=2.915$, RMSEA $=.089 \mathrm{GFI}=.920$, AGFI $=.862$, CFI $=.970$ ).

Construct validity was tested by convergent and discriminant tests. To test the construct validity Gaskin Stat tools (Gaskin, 2016) were used. All factors loaded were significant and acceptable. The value of average variance extracted was (AVE $>0.5)$ and the value of composite reliability also exceeded the benchmark $(\mathrm{CR}>0.7)$. In the composite reliability test it was observed that the value of average variance extracted was greater than the value of maximum shared value (AVE $>$ MSV).

The model tested six components for the measure of organizational structure, which was consistent with the results of the exploratory factor analysis conducted using principal component analysis, 6 items were loaded onto the control factor; 4 items were loaded on autonomy factor, 4 items were loaded on centralization, 3 items were loaded on coordination factor, 4 items were loaded on specialization factor, and 3 items were loaded on formalization. The confirmatory factor analysis on organizational structure; items 14, 19, 23, and 24 were eliminated due to low loading coefficients. It was concluded that the model was fit $\left(\chi 2=304.750 ; \mathrm{df}=155 ; \mathrm{P}=0.00, \chi^{2} / \mathrm{df}=1.96, \mathrm{RMSEA}=.069, \mathrm{GFI}=.878, \mathrm{AGFI}=.835, \mathrm{CFI}=\right.$ $.891)$.

Construct validity was tested by convergent and discriminant tests. The average variance extracted value of 3 variables were greater than 0.05 (AVE > 0.05) and the AEV of other three variable was less than 0.05 . The value of composite reliability exceeded the benchmark $(C R>0.6)$. Composite reliability showed that the highest value of average variance extracted was greater than the value of maximum shared value (AVE > MSV).

The model tested three factors on the measure of job performance, which was consistent with the results of the EFA conducted using principal component analysis. On the model, 4 items loaded the task performance, 3 items loaded time management, and 3 items loaded contextual performance. The CFA on job performance suggested modifications to add error variance correlation between the error items 10 and 7. Items 7,8 , and 16 were eliminated since they loaded components lower than the threshold values. It was concluded that the model was fit $(\chi 2=50.840 ; \mathrm{df}=31 ; \mathrm{p}=0.014 ; \chi 2 / \mathrm{df}=1.640, \mathrm{RMSEA}=0.056$, $\mathrm{GFI}=0.950, \mathrm{AGFI}=0.912$ ).

The value of average variance extracted was (AVE $>0.5)$ and the value of composite reliability exceeded the benchmark $(\mathrm{CR}>0.6)$. Composite reliability showed that the value of average variance extracted was greater than the value of maximum shared value (AVE $>$ MSV).

\section{Covariance}

Covariance is the degree in which two different random variables change with respect each other. Covariance matrix directed the researcher to use a stepwise regression in determining which variable can be eliminated from the model to find a significant model with minimum variables. Covariance analysis is a powerful and useful analysis used to minimize the error variance and increases the strength of the model (Burgazoglu, 2013). There are two main objectives of covariance analysis. Firstly, it removes any systematic error which could affect the results. Secondly its purpose is to clarify the differences between results of certain characterized groups. Systematic error can be removed by random sampling in an empirical analysis but in real life is not always possible due to the difficulty of random sampling. Therefore the use of covariance become a necessity (Burgazoglu, 2013, p. 19). 


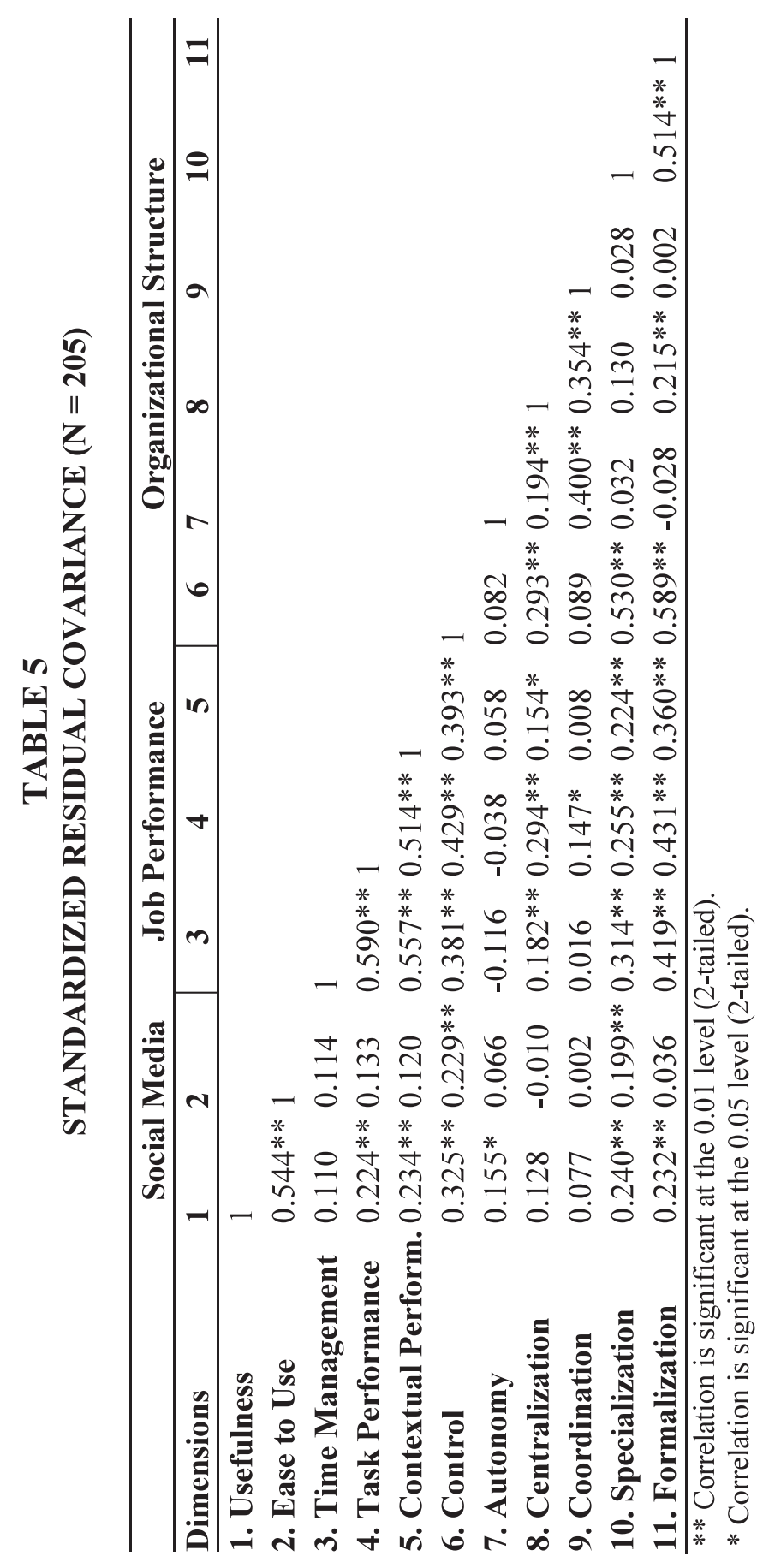


Table 5 show the results of covariance among the variables. It was examined that the measurements model was largely supported by the data. Assessment of the bivariate correlation show that variables were significantly correlated with each other. Specially, component "usefulness" of social media was highly correlated with task performance and contextual performance. Similarly, it was strongly correlated with control, specialization and formalization. Whereas, component "ease to use" of social media has no correlation with any component of employee job performance. Furthermore, component "ease to use" of social media strongly correlated with organizational structure (control and specialization) and negatively correlated with centralization. Component time Management was highly correlated with control, specialization, centralization and formalization while negatively correlated with autonomy. Likewise, task performance of employees was highly strong correlated with control, centralization, specialization, formalization and weakly correlated with coordination. While the task performance was negatively correlated with autonomy. Similarly, contextual performance was highly correlated with control, specialization and formulation and weakly correlated with the centralization.

\section{Structural Equation Modelling}

Structural Equation Modelling (SEM) is a very flexible and comprehensive method in representing, testing a relationship between measured (observed) variables and latent constructs. SEM enables us to understand the correlation (co-variance) among the variables. SEM also explains much of their variance as possible with specified model. SEM allows the researchers to determine the strength of relationships between the constructs. One of the main application of structural equation model is path analysis, which hypothesize between variables and test models with linear equation (Liu \& Hsiang, 2015, p. 784). Indeed, SEM is increasingly being used as a useful quantitative method for specifying, estimating, and testing hypothetical theoretical models that describe the relationships between variables. It focuses on the validity of models and directional effects between the parameters of the model (Lei \& Lomax, 2009, p. 1).

There are more than ten different fit indices to choose from in determining how well the theoretical model is at forecasting endogenous variables.

\section{FIGURE 2 \\ STRUCTURAL EQUATION MODELING}

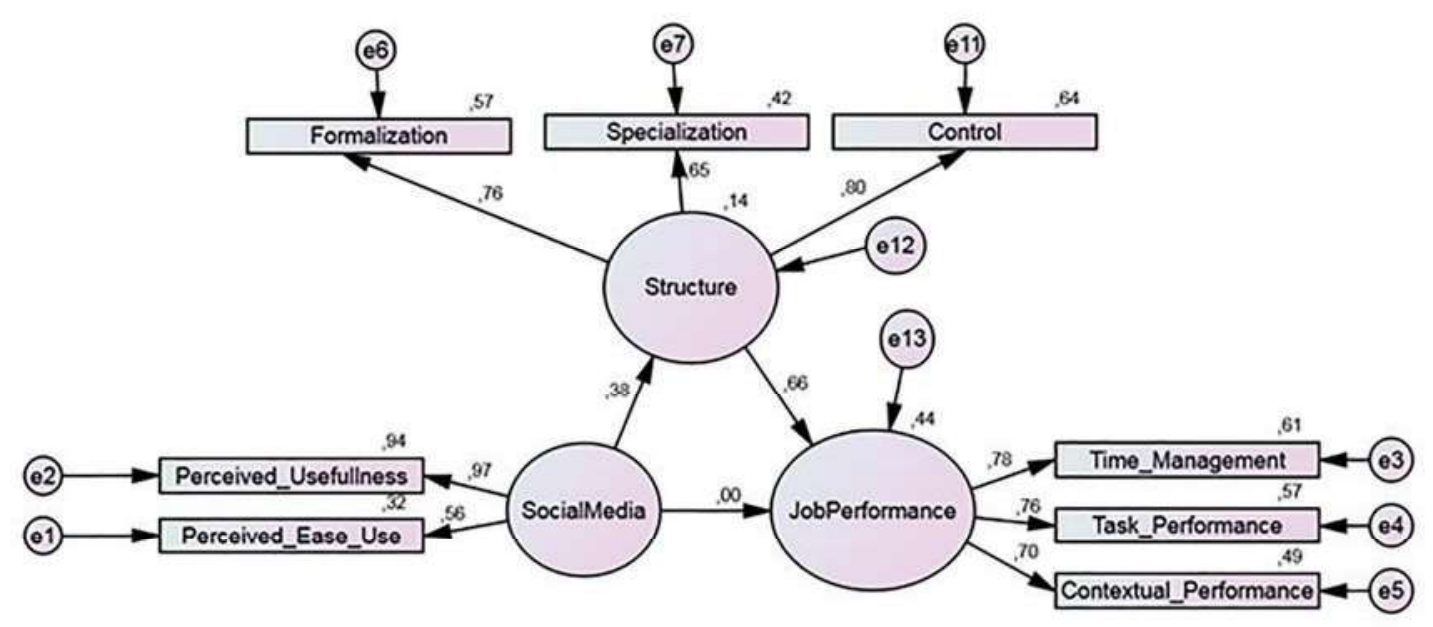

Chi Square: 30,105; Degree of freedom: 17; p: ,026

Figure 2 shows the structural equation model of this research. In this model exogenous variable social media contained two factors; usefulness and ease to use. Indigenous variable job performance comprised 
of three factors: time management, task performance and contextual performance. Indigenous variables of organizational structure contained three factors: specialization, formalization, and control. Three factor coordination, autonomy and centralization were eliminated due to low loading coefficients. The below Table 6 provides a short list of fit indices used in SEM (Walker \& Maddan, 2013). It was concluded that the findings on the table are model yielded statistically fit indices.

TABLE 6

FIT INDICES OF THE MODEL

\begin{tabular}{lllc}
\hline Shorthand & Index of Fit & Model is Accepted if* & Findings \\
\hline GFI & Goodness of fit index & $>0.90$ & 0.966 \\
AGFI & Adjusted goodness of fit index & $>0.90$ & 0.928 \\
CFI & Comparative fit index & $>0.90$ & 0,975 \\
TLI & Tucker-Lewis index & $>0.90$ & 0,958 \\
NFI & Normed fit index & $>0.80$ & 0,945 \\
RMR & Root Mean Square Residual & 0 indicates perfect fit & 0.034 \\
RMSEA & Root Mean Square Error of Approximation & $<0.08$ & 0.061 \\
$\chi^{2}$ & Relative Chi-square & $\chi^{2} / d f \leq 3$ and $\mathrm{p}>0.05$ & 1.771 \\
\hline
\end{tabular}

* Source: (Walker \& Maddan, 2013; Schreiber et al., 2006).

When structural equation model was analyzed, linear effect was investigated in this research model. The direct effect model showed acceptable fit indices $(\chi 2=7.882$ (4), p b.096; GFI = .986; AGFI; .946; RMSEA $=.069)$. A positive relationship between the use of social media and employee job performance $(\mathrm{H} 1: \beta=.21, \mathrm{p}: 0.004)$ was supported. Table 7 presents a summary of the model estimates.

TABLE 7

AMOS STANDARDIZED REGRESSION WEIGHTS

\begin{tabular}{lllc}
\hline & & & Estimate \\
\hline Structure & $<---$ & Social Media &, 376 \\
Job Performance & $<---$ & Social Media &, 004 \\
Job Performance & $<---$ & Structure &, 662 \\
Perceived Ease to Use & $<---$ & Social Media &, 563 \\
Perceived Usefulness & $<---$ & Social Media &, 967 \\
Time Management & $<---$ & Job Performance &, 780 \\
Task Performance & $<---$ & Job Performance &, 756 \\
Contextual Performance & $<---$ & Job Performance &, 699 \\
Specialization & $<---$ & Structure &, 652 \\
Control & $<---$ & Structure &, 800 \\
Formalization & $<---$ & Structure &, 757 \\
\hline
\end{tabular}

Depicted in Figure 2, SEM was analyzed to determine the relationship between variables. It was observed that SEM was fulfilled the conditions of the mediating effect. It was concluded that social media has a significant effect on organization structure $(\beta=.38, \mathrm{p}: 0.000)$. Similarly, Organizational structure also has significant effect on job performance $(\beta=.66, \mathrm{p}: 0.000)$. In indirect effect, it was observed that social media has no significant effect on job performance $(\beta=.00, \mathrm{p}: 0.959)$. Hence, organizational structure has mediating effect on the relationship between the use of social media and employee job performance. Thus, it was concluded that Hypothesis $\mathrm{H}_{2}$ was supported. 


\section{DISCUSSION}

This research contributes to the literature and provides managerial insight related to social media usage in organizations. Results supported the previous research hypotheses and indicates that the use of social media has positive effect on an employees' job performance. Findings of this research are also consistent with the work of (Ali-Hassan, Nevo, \& Wade, 2015b) as their study analyzed the linking dimensions of social media use to job performance and found that social and cognitive use of social media have a positive effect on an employee's routine and innovative job performance. Moreover, the study partially support the work of Lu et al., (2015) that hedonic use of social media have negative effects on routine performance. In addition to that, (Lu et al., 2015) worked regarding corporate blogging and Job Performance is confirmed as the present findings showed that blog network has positive effects on job performance.

Another important contribution of this research is the effect of organizational structure on employees' job performance. Findings in this research were significant and consistent with the literature at hand. (Shafiee et al., 2016) investigated the relationship between organizational structure factors and personnel performance and concluded that there is a positive relationship between organizational structure and employee job performance. (Ajagbe et al., 2016) conducted a research to answer the following question "how organizational structure aids business performance", concluded that organization structure has positive impact on specialization of work processes and productivity of employees. The present findings are consistent with the work of aforementioned literature.

\section{CONCLUSION AND RECOMMENDATIONS}

In this research, the relationship between use of social media and employee job performance with the mediating role of organizational structure was investigated. Results indicated that there is a positive relationship between the use of social media and job performance. Moreover, organizational structure has a mediating role between these two variables.

Findings proved that employees perceive social media as a useful tool at workplace and has strong effect on their performance. Similarly, practitioners prefer to use social media at workplace to increase performance of their employees. Results supported that "usefulness" component of social media strongly correlated with employee job performance especially with task performance and contextual performance. Hence, it is suggested that higher management ought to develop policies, procedures, rules and regulation abut social media usage and encourage them to use it for work purposes at workplace to gain its utmost benefits.

It was concluded that organizational structure fulfills the assumption of mediating role in regards to the relationship between social media usage and employee job performance. Social media drives organizations to decentralization and enable employees make prompt decisions. This in return increases customer satisfaction and business competitive advantage. Therefore, management in organizations should create a structure where social media can also be a part of their business process and help to increase employee job performance. Management should also focus to learn how these technologies integrate with existing systems to support their employee's capabilities.

This research has some limitations that offers further research opportunities. Firstly, this research was conducted in Turkey, which means that the generalizability is region and context specific. A Similar research could be conducted in other countries as organizational phenomena may differ in different cultures. Secondly, this research only focused on social media usage at the workplace in the service sector. Therefore, researchers may explore different effects on the dimensions of social media (social, cognitive, hedonic) and on other variables of employee job performance (routine performance and innovative performance). Further researches can also be conducted in other sectors for comparisons because comparative analysis would reveal for in-depth understanding of the variables of interest.

Journal of Organizational Psychology Vol. 18(4) 2018112 


\section{REFERENCES}

Acharya, A., \& Mishra, B. (2017). Exploring the relationship between organizational structure and knowledge retention: a study of the Indian infrastructure consulting sector. Journal of Knowledge Management, 21(4), 961-985.

Aichner, T., \& Jacob, F. (2014). Measuring the degree of corporate social media use. International Journal of market research, 57(2), 257-273.

Ajagbe, M. A., Cho, N. M., \& Udo, E. E. U. (2016). How Organizational Structure Aids Business Performance. International Journal Of Research In Commerce \& Management, 7(8), 64-68.

Akkoc, İ., \& Erdogan, B. Z. (2011). Organizasyon Yapısı ve Liderliğin İş Performansına Etkisi. Çăg Üniversitesi Sosyal Bilimler, 8(1), 108.

Ali-Hassan, H., Nevo, D., \& Wade, M. (2015a). Linking dimensions of social media use to job performance:The role of social capital. Journal of Strategic Information Systems, 24, 65-89.

Ali-Hassan, H., Nevo, D., \& Wade, M. (2015b). Linking dimensions of social media use to job performance:v The role of social capital. Journal of Strategic Information Systems, 24(3), 65-89.

Atsan, M., \& Çetinkaya, A. Ş. (2015). Yönetim Başarısında Sosyal Medyanın Rolü: İş Dünyasından Örnek Olaylar. Paper presented at the I. Eurasia International Tourism Congress: Current Issues, Trends, and Indicators (EITOC-2015), 28 - 30 May 2015, Konya, Turkey.

Bartholomew, D., Knott, M., \& Moustaki, I. (2011). Latent Variable Models and Factor Analysis: A Unified Approach: Wiley Series.

Betsy A. Pudliner, Eric T. Brey, \& Hyeong-Gyu Choi. (2015). The Emergence of Social Media: A Research Narrative Review. Society for Marketing Advances Proceedings, 406-407.

Borman, W. C., \& Motowidlo, S. J. (1997). Task Performance and Contextual Performance: The Meaning for Personnel Selection Research Human Performance, 10(2), 99-109

Burgazoglu, H. (2013). Çok Değişkenli Kovaryans Analizi Ve 360 Derece Performans Dĕ̆erlendirmesi Üzerine Bir Uygulama.

Cai, Z., Huang, Q., \& Liu, H. (2018). Improving the agility of employees through enterprise social media: The mediating role of psychological conditions. International Journal of Information Management, 38, 52-63.

Caillier, J. G. (2010). Factors Affecting Job Performance in Public Agencies. Public Performance \& Management Review, 34(2), 139-165.

Cao, X., \& Ali, A. (2018). Enhancing team creative performance through social media and transactive memory system. International Journal of Information Management, 39, 69-79.

Cao, X., Guo, X., Vogel, D., \& Zhang, X. ( 2016). Exploring The Influence Of Social Media On Employee Work Performance. Emerald Group Publishing Limited, 26(2), 529-545.

Carr, C. T., \& Hayes, R. A. (2015). Social Media: Defining, Developing, and Divining. Journal of Communication, 23, 46-65.

Catalsakal, S. (2016). How Trait Mindfulness Is Related To Job Performance And Job Satisfaction: SelfRegulation As A Potential Mediator. (Master of Science), Middle East Technical University.

Coole, D. R. (2003). The effects of citizenship performance, task performance, and rating format on performance judgments. (Master), University of South Florida.

Daowd, A. (2016). The Impact of Social Media on the Performance of Microfinance Institutions in Developing Countries: A Quantitative Approach.

Delic, A., \& Ahmetovic, E. (2013). Characteristics Of Organizational Structure Of Bosnian And Herzegovinian Companies. Journal of Economics and Business, XI(2), 31-43.

Dinc, M. S. (2017). Organizational Commitment Components and Job Performance: Mediating Role of Job Satisfaction. Pakistan Journal of Commerce and Social Sciences, 11(3), 773-789.

Dunne, A., Lawlor, M.-A., \& Rowley, J. (2010). Young people's use of online social networking sites - a uses and gratifications perspective. Journal of Research in Interactive, 4(1), 46-58.

Fusi, F., \& Feeney, M. K. (2016). Social Media in the Workplace: Information Exchange, Productivity, or Waste? American Review of Public Administration, 1-23. 
Gaskin, J. (2016). Excel StatTools. Stats tools package. Retrieved from http://statwiki.kolobkreations.com/

Gerald C. Kane, \& Maryam Alavi. (2012). What's Different About Social Media Networks? A Framework And Research Agenda. Retrieved from

Goldkind, L. (2015). Social Media and Social Service: Are Nonprofits Plugged In to the Digital Age? Human Service Organizations: Management, Leadership \& Governance, 39, 380-396.

haman, O. (2016). Örgüt Yapisi Ve Örgütsel İletişsim Arasındak İlişskinin Belirlenmesi Üzerine Bir Araştirma. Nişantaşi Ünİversitesi Sosyal Bilimler Enstitüsü.

Hao, Q., Kasper, H., \& Muehlbacher, J. (2012). How does organizational structure influence performance through learning and innovation in Austria and China. Chinese Management Studies, 6(1), 36-52.

Harandi, S. R., \& Abdolvand, N. (2018). Investigating the Effect of Online and Offline Workplace Communication Networks on Employees' Job Performance: Considering the Role of Culture. Journal Of Global Information Technology Management, 21(1), 26-44.

Harari, M. B., Reaves, A. C., \& Viswesvaran, C. (2015). Creative and innovative performance: a metaanalysis of relationships with task, citizenship, and counterproductive job performance dimensions. European Journal of Work and Organizational Psychology, 25(4), 495-511.

Hernandez, B., Stanley, B., \& Miller, L. (2014). Job Embeddedness and Job Engagement: Recommendations for a Supportive Social Work Environment. Human Service Organizations: Management, Leadership \& Governance, 38, 336-347.

Hox, J. J., \& Bechger, T. M. (2006). An Introduction to Structural Equation Modeling. Family Science Review, 354-373.

Huang, X., Kristal, M. M., \& Schroeder, R. G. (2010a). The Impact of Organizational Structure on Mass Customization Capability: A Contingency View. Production and Operations Management, 19(5), 515-530.

Huang, X., Kristal, M. M., \& Schroeder, R. G. (2010b). The Impact of Organizational Structure on Mass Customization Capability: A Contingency View. Production and Operations Management Society, 19(5), 515-530.

Islek, M. S. (2012). Sosyal Medyanin TüketícI Davranişlarina EtkIlerİ: TürkIye'dekİ Sosyal Medya Kullanicilari Üzerine Bİr Araştirma. (Yüksek Lisans), Karamanoğlu Mehmetbey Ünİversİtesí.

Jana Kühnel, Tim Vahle-Hinzc, \& Bloom, Jessica d. (2017). Staying in touch while at work: Relationships between personal social media use at work and work-nonwork balance and creativity. The International Journal of Human Resource Management, 1-27.

Janićijević, N. (2017). Organizational Models As Configurations Of Structure, Culture, Leadership, Control, And Change Strategy. Economic Annals, 67-91.

Kane, G. C. (2015). Enterprise Social Media: Current Capabilities and Future Possibilities. MIS Quarterly Executive, 14(1), 1-16.

Kane, G. C. (2017a). The evolutionary implications of social media for organizational knowledge management. Information and Organization, 27, 37-46.

Kane, G. C. (2017b). The evolutionary implications of social media for organizational knowledge management. Information and Organization, 27, 37-46.

Kaplan, A. M., \& Haenlein, M. (2012). Social media: back to the roots and back to the future. Journal of Systems and Information Technology, 14(2), 101-104.

Kjaerulff, C. (2015). Organizational Structure's Influence on Social Media. (Master).

Koopmans, L., \& Bernaards, C. M. (2014). Construct Validity of the Individual Work Performance Questionnaire. journal of Environmental Medicine, 56(3), 331-337.

Langer, E. (2014). What's Trending? Social Media and its Effects on Organizational Communication. Journal of Undergraduate Research, XVII, 1-14.

Lei, M., \& Lomax, R. G. (2009). The Effect of Varying Degrees of Nonnormality in Structural Equation Modeling. Structural Equation Modeling: A Multidisciplinary Journal, 4(1), 1-27.

Levy, M. (2013). Stairways to heaven: implementing social media in organizations. Journal of Knowledge Management, 17(5), 741-754. 
LI, Y., \& Lu, J. (2009). Review on Employee Job Performance Dimensions. IEEE.

Liao, C., Chuang, S.-H., \& To, P.-L. (2011). How knowledge management mediates the relationship between environment and organizational structure. Journal of Business Research, 64, 728-736.

Liu, M. M. R. M., \& Hsiang, S. M. (2015). Planning for uncertainty: use of structural equation modelling to determine the causal structure of time buffer allocation. Construction Management and Economics, 33(10), 783-798.

Liua, S., Jiangb, K., \& Chen, J. (2016). Linking employee boundary spanning behavior to task performance: the influence of informal leader emergence and group power distance. The International Journal of Human Resource Management, 1-21.

Louie H. M. Wong, Carol X. J. Ou, Davison, R. M., Hui Zhu, \& Zhang, C. (2016). Web 2.0 and Communication Processes at Work: Evidence From China. IEEE Transactions On Professional Communication, 59(3), 230-244.

Lu, B., Guo, X., Luo, N., \& Chen, G. (2015). Corporate Blogging and Job Performance: Effects of Workrelated and Nonwork-related Participation. Journal of Management Information Systems, 32(4), $285-314$.

Macnamara, J., \& Zerfass, A. (2012). Social Media Communication in Organizations: The Challenges of Balancing Openness, Strategy, and Management. Journal of Strategic Communication, 6, 287308.

Madsen, D. O., \& Slatten, K. (2015). Social media and management fashions. Cogent Business \& Management, 2, 2-17.

Marsh, H., Morin, A. J. S., Parker, P. D., \& Kaur, G. (2014). Exploratory Structural Equation Modeling: An Integration of the Best Features of Exploratory and Confirmatory Factor Analysis. Annual Review of Clinical Psychology, 10, 85-110.

McPhail, C. J. (2016). From Tall to Matrix Redefining Organizational Structures. Retrieved from

Meriçöz, S. (2015). Çalişanlarin Örgütsel Adalet Algilarinin İş Tatmİİne Ve İş Performansina Olan Etkìİ: Ampİ̀İk Bİr Çalişma. (Yükssek Lisans), Bahçeşehİr Ünİversİtesi̇.

Nga Ling Chan, \& Guillet, B. D. (2011). Investigation of Social Media Marketing: How Does the Hotel Industry in Hong Kong Perform in Marketing on Social Media Websites? Journal of Travel \& Tourism Marketing, 28:345-368, 2011, 28, 345-368.

Nisar, A., Rodríguez-Monroy, C., Ruiz, F., \& Yuxi, W. (2012). Organizational Structure Shapes Performance in Dynamic Environments: Studying the Relationship Between Structure and Performance. Industrial Engineering: Innovative Networks, 175-180. doi:10.1007/978-1-44712321-7_20

Özdemir, S., \& Erdem, R. (2016). Sosyal Medyanin Örgüt İçİ İletİşİmdekİ Rolü. MANAS Journal of Social Studies, 5(4), 247-269.

Özlem Çetinkaya Bozkurta, Adnan Kalkanb, \& Armanc, M. (2014). The Relationship between Structural Characteristics of Organization and Followed Business Strategy: An application in Denizli. Social and Behavioral Sciences, 150, $222-229$

Pan, B. (2012). Theoretical Models of Social Media, Marketing Implications, and Future Research Directions. Retrieved from

Perrin, A. (2015). Social Media Usage: 2005-2015 Retrieved from

Reitz, A. (2012). Social Media's Function in Organizations: A Functional Analysis Approach. Global Media Journal, 5(2), 41-56.

Sani, A., \& Maharani, V. (2015). Relationship between Human Resource Management (HRM) Practices and Organizational Performance Moderated by Organizational Commitment. Australian Journal of Basic and Applied Sciences, 9(7), 185-188.

Sashi, C. M. (2012). Customer engagement, buyer-seller relationships, and social media. Emerald Group Publishing Limited, 50(2), 253-272.

Scott, W. R., \& Davis, G. F. (2014). Organizations and Organizing Rational, Narual and Open Systems Perspectives. Edinburgh: Pearson Education Limited. 
Sethela June, \& Mahmood, R. (2011). The Relationship Between Person-Job Fit And Job Performance: A Study Among The Employees Of The Service Sector Smes In Malaysia. International Journal of Business, Humanities and Technology, 1(2), 95-105.

Shaar, E. M. A., \& Khattab, S. A. (2015). The Effect of Top Management Support on Innovation: the Mediating Role of Synergy Between Organizational Structure and Information Technology. International Review of Management and Business Research, 4(2), 409-513.

Shafiee, H., Razminia, E., \& Zeymaran, N. K. (2016). Investigating the Relationship between Organizational Structure Factors and Personnel Performance. International Journal of Management, Accounting and Economics, 3(2), 160-165.

Stone-Romero, E. F., Alvarez, K., \& Thompson, L. F. (2009). The construct validity of conceptual and operational definitions of contextual performance and related constructs. Human Resource Management Review, 19, 104-116.

Sujarwoto. (2017). Why decentralization works and does not works? A systematic literature review. Journal of Public Administration Studies, 1(3), 1-10.

Sykes, T. A., Venkatesh, V., \& Johnson, J. L. (2014). Enterprise System Implementation And Employee Job Performance: Understanding The Role Of Advice Networks. Mis Quarterly, 38(1), 51-72.

Tajudeen, F. P., Jaafar, N. I., \& Ainin, S. (2018). Understanding the impact of social media usage among organizations. Information \& Management, 55, 308-321.

Tajvidi, R., \& Karami, A. (2017). The effect of social media on firm performance. Computers in Human Behavior, 1-10.

Tran, Q., \& Tian, Y. (2013). Organizational Structure: Influencing Factors and Impact on a Firm. American Journal of Industrial and Business Management, 3, 229-236

Tufail, M. S., Mahesar, H. A., \& Pathan, S. K. (2017). Organizational Justice, Task And Contextual Performance: Empirical Analysis For Front Line Managers. Grassroots, 51(1), 269-281.

Uryan, E. (2015). The Role Of Distributive Justice And Work Engagement As The Antecedents Of Affective Commitment And Job Performance: An Empirical Study In A Bank. (M.Sc), Istanbul Technical University.

Usher, W. (2011). Types of Social Media (Web 2.0) Used by Australian Allied Health Professionals to Deliver Early Twenty-First-Century Practice Promotion and Health Care. Social Work in Health Care, 50, 305-329,.

Veale, J. F. (2014). Edinburgh Handedness Inventory - Short Form: A revised version based on confirmatory factor analysis. Laterality: Asymmetries of Body, Brain and Cognition, 19(2), 164 177.

Wahba, M. (2015). The Impact Of Organizational Structure On Knowledge Management Processes In Egyptian Context. Journal of Developing Areas, 49(3), 275-292.

Walker, J., \& Maddan, S. (2013). Statistics in criminology and criminal justice (4 ed.): Jones \& Bartlett Learning.

Wang, M.-H., Yang, T.-Y., \& Chen, Y.-S. (2016). How Workers Engage In Social Networking Sites At Work: A Uses And Gratification Expectancy Perspective. International Journal of Organizational Innovation, 8(4), 161-176.

White, M. (2014). The impact of social media on employee performance - a study by IBM Research. Retrieved from "http://www.intranetfocus.com/archives/1893"

Yong, A. G., \& Pearce, S. (2013). A Beginner's Guide to Factor Analysis: Focusing on Exploratory Factor Analysis. Tutorials in Quantitative Methods for Psychology, 9(2), 79-94.

Young, J. A. (2017). Facebook, Twitter, and Blogs: The Adoption and Utilization of Social Media in Nonprofit Human Service Organizations. Human Service Organizations: Management, Leadership \& Governance, 41(1), 44-57.

Zhang, \& Venkatesh, V. (2013). Explaining Employee Job Performance: The Role Of Online And Offline Workplace Communication Networks. MIS Quarterly, 37(3), 695-722.

Zhang, M., Zhao, X., \& Qi, Y. (2014). The effects of organizational flatness, coordination, and product modularity on mass customization capability. Int. J. Production Economics, 158, 145-155. 